\title{
MHC-II MARKER POTENTIAL LINKED TO MOTILE AEROMONAD SEPTICAEMIA DISEASE RESISTANCE IN AFRICAN CATFISH (Clarias gariepinus)
}

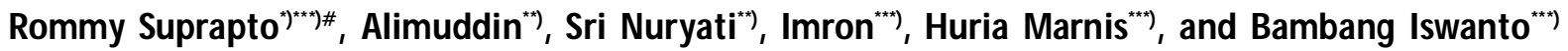 \\ *) Postgraduate Student, Department of Aquaculture, Bogor Agricultural University \\ *) Department of Aquaculture, Faculty of Fisheries and Marince Science, Bogor Agricultural University \\ **) Research Institute for Fish Breeding
}

(Received 29 May 2017; Final revised 27 July 2017; Accepted 27 July 2017)

\begin{abstract}
One of the important issues in catfish farming is motile aeromonad septicaemia (MAS) disease caused by the bacterium Aeromonas hydrophila. This study aimed to find the MHC-II marker potential for marker-based selection to generate MAS disease resistance of African catfish. PCR method was applied to identify catfish (body length: 7-8 cm) population that have MHC-II marker. Fish with and without the marker were then challenged by intraperitonially injecting of $0.1 \mathrm{~mL} / \mathrm{fish}$ with A. hydrophila $\left(10^{5} \mathrm{cfu} / \mathrm{mL}\right)$. The results showed that the survival of fish having MHC-II marker $(77.50 \pm 4.00 \%$ was higher than that of fish without the marker $(53.33 \pm 4.77 \%$. Fish carrying MHC-II marker fish has also higher total erythrocytes, total leukocytes, phagocytic activity, and hematocrit levels than that of fish without the marker. The PCR results using specific primer for MHC-II showed a specific DNA band of 426 bp in fish having the marker, while there were no DNA bands in fish without the marker. Results of the PCR analyses showed that the percentage of progenies carrying MHC-II marker was $80 \%$ while progenies from broodstock without the marker was $0 \%$ this indicated that MHC-II marker could be inherited to the offsprings. Thus, the MHC-II marker could be used as a molecular marker of MAS disease resistance catfish.
\end{abstract}

\section{KEYWORDS: catfish; Aeromonas hydrophila; MAS; molecular markers; MHC-II}

\section{INTRODUCTION}

Intensive aquaculture systems potentially induce stress in fish, resulting in lower levels of immunity so that the fish is susceptible to disease. Motile aeromonad septicaemia (MAS) is one of the diseases that attack catfish caused by infection of bacterium Aeromonas hydrophila. MAS is an acute bacterial disease and can infect all stadia and types of freshwater fish, and can result in the death of up to $100 \%$ (Taukhid et al., 2015). Protective and preventive efforts against MAS disease is still performed through external immunity improvement (inducible), usually using immunostimulant (Wahjuningrum et al., 2010); but its application is rather difficult and should be at precise dosage. In addition, the use of antibiotics may solve the problem, but in fact it can lead to increase residues of antibiotics and antibiotic resistance in fish, and causes environmental pollution (Poonsawat et al.,

\# Correspondence: Research Institute for Fish Breeding. Jl. Raya Sukamandi No. 2, Subang 41256, Indonesian. Phone: + (0260) 520500

E-mail: publikasi.bppi@gmail.com
2009). Therefore, finding the other alternative solutions to deal with MAS diseases is required.

A promising solution to avoid the use of antibiotics and other chemicals is through the selection of fish based on molecular markers. Selection is carried out with aid of genes associated with the immune system. Major histocompatibility complex (MHC) is one of the candidate of gene markers. MHC has been most studied in molecular biology, because MHC genes encode receptor molecules that recognize and bind foreign objects, and then present to the immune cells, leading to increase in immune response (Rakus, 2008). The distinctive feature of MHC genes is a high degree of polymorphism which can provide response options to the pressure exerted by pathogens and parasites (Seifertova \& Simkova, 2011).

A study related to $\mathrm{MHC}$ in catfish (Clarias sp.) which indicated that MHC-I could be a molecular marker of catfish that was resistant to A. hydrophila infection was conducted by Aziz et al. (2015a). MHC$\mathrm{I}$ is expressed by all nucleated cells and platelets, whereas MHC-II is restrictly expressed. Therefore, 
MHC-II studies mainly on catfish are needed to strengthen data and information on the specific immune response in catfish. Specific alleles of MHC-II have been shown to correlate to disease resistance in tilapia (Pang et al., 2013), goldfish (Alimuddin et al., 2011; Hayuningtyas et al., 2013), eel (Li et al., 2014), and channel catfish (Moulana et al., 2008). This study aimed to find the candidate MHC-II marker on molecular marker-based selection to produce catfish resistant to MAS.

\section{MATERIALS AND METHODS}

\section{Time and Location of Research}

This study was conducted in January-September 2016. Broodstock selection, fish rearing, and hematology study were conducted in hatchery and experimental ponds; and analysis of DNA marker was conducted in the Laboratory of Genetics and Physiology of Research Institute for Fish Breeding (RIFB) Sukamandi, Subang, West Java, Indonesia.

\section{Preparation of Experimental Fish and Container}

Fish containers used were 21 aquaria with dimension of $60 \mathrm{~cm} \times 40 \mathrm{~cm} \times 25 \mathrm{~cm}$. The water volume was set at $60 \mathrm{~L}$, and aeration was added in each aquarium (at density of 10 fish) to supply oxygen. Experimental catfish (body length 7-8 cm) used in this study was Mutiara strain, supplied from RIFB. Selected broodstocks (carrying and without MHC-II marker, identified using PCR method) were then mated in pairs (male and female ratio was 1:1). After getting five pairs of candidates for the basic population of each group, a total of 500 larvae at two-day-old from each pair were transferred and reared in an aquarium to be used as samples for test of disease resistance.

The bacteria used to infect catfish seeds were A. hydrophila obtained from Research and Development Installation for Fish Disease Control, Depok. The iso late of A. hydrophila was placed into Tryptic Soy Agar (TSA) media and incubated at $27^{\circ} \mathrm{C}$ for 48 hours, then the culture was resuspended in Phosphate-Buffered Saline (PBS) solution to reach density of $10^{8} \mathrm{CFU} / \mathrm{mL}$ as the culture stock.

\section{Determination of $\mathbf{L D}_{50}$ and Challenge Test}

The experimental fish for $L_{50}$ test was fish not selected to have MHC-II marker or not. Determination of $\mathrm{LD}_{50}$ was carried out by intramuscularly injecting bacteria with a density of $10^{4}, 10^{5}, 10^{6}, 10^{7}$, and $10^{8} \mathrm{CFU} / \mathrm{mL}$ at volume of $0.1 \mathrm{~mL} /$ fish. All treatment groups were performed at triplicates. Observations were carried out by determining proportion of dead and live fish until the $4^{\text {th }}$ day, then $\mathrm{LD}_{50}$ was calculated according to the method of Reed \& Muench (1938). The result of $L D_{50}$ test was used in challenge test via intramuscular injection, with the same container and fish density as $L_{50}$ test.

\section{Experimental Variables}

The parameters studied were survival rate (observed daily until the end of treatment), clinical symptoms, blood picture analysis, and detection of MHCII markers. Survival rate was determined as follow:

$$
\mathrm{SR}=\frac{\sum \text { live fish at the end of treatment }}{\sum \text { fish at the initial period of treatment }} \times 100
$$

Parameters for clinical symptoms included behavioral, reflex motion, and abnormalities (inflammation), which were observed daily for 12 days after injection of A. hydrophila. Blood samples of three fish (each treatment) were collected using a fitted with a 1-mL gauge needle. Blood withdrawal was performed once in three days during challenge test against $A$. hydrophila. Blood sample was transferred into polyethylene tube rinsed with sodium citrate (concentration of $3.8 \%$. Furthermore, total erythrocytes, total leukocytes, phagocytic activity, and hematocrit levels were observed. The number of erythrocytes and total leukocytes were calculated using methods of Nabib \& Pasaribu (1989); whereas phagocytic activity and hematocrit levels were analysed using the method of Anderson \& Siwicki (1993). The fish used in hematological experiment was from different replicates from fish samples used in survival rate.

Presence of MHC-II marker was determined using a polymerase chain reaction (PCR) method. Genomic DNA was extracted from fin tissues of live and dead fish after challenge test. Genomic DNA extraction was carried out using Genejet Genomic DNA Purification kit (Thermo Scientific, USA) according to the procedure in the manual kit. The genomic DNA was then amplified using PCR mycycler machine (Biorad, USA) and using Maxima green hot start PCR Master Mix (2x) (Fermentas, Thermo Scientific). Primer 2B for MHCII markers in catfish was designed by aligning the MHC-II alleles of Channel catfish (Ictalurus punctatus) and $\mathrm{C}$. gariepinus. The sequences were aligned using Basic local alignment search tool (BLAST ${ }^{\circledR}$ ). Composition of PCR reagent included $1 \mu \mathrm{L}$ of $2 \mathrm{~B}$ primer forward; $1 \mu \mathrm{L}$ of $2 \mathrm{~B}$ primer reverse with a concentration of $10 \mathrm{pmol} / \mathrm{iL} ; 1 \mu \mathrm{L}$ of DNA; $12.5 \mu \mathrm{L}$ of kit Master mix PCR, and $8.5 \mu \mathrm{L}$ of nuclease free water. PCR amplification was pre-denaturation at $95^{\circ} \mathrm{C}$ for 4 minute; 35 cycles of PCR with denaturation at $95^{\circ} \mathrm{C}$ for 30 
second, annealing at $55^{\circ} \mathrm{C}$ for 1 minute, and extension at $72^{\circ} \mathrm{C}$ for 1 minute; and a final extension at $72^{\circ} \mathrm{C}$ for 10 minute. As an internal control loading genomic DNA, $\beta$-actin was used (Alimuddin et al., 2008). Electrophoresis was carried out using $2 \%$ of agarose gel (w/v), at a voltage of 60 volts for $60 \mathrm{~min}$. DNA was visualized using gel red (Biotum Inc. California, USA) and subsequently visualized using UV gel doc transilluminator.

\section{RESULTS AND DISCUSSION}

\section{Determination of $\mathbf{L D}_{50}$}

Results of $L D_{50}$ test of $A$. hydrophila were exhibited in Figure 1. Our data showed that higher dose of A. hydrophila was responsible for lower survival rate. The highest mean of survival rate $(73.33 \%$ was attributed to dose $10^{4} \mathrm{cfu} / \mathrm{mL}$, while the lowest value $\left(13.33 \%\right.$ was attributed to dose $10^{8} \mathrm{cfu} / \mathrm{mL}$. Using a method prescribed by Reed \& M uench (1938), LD ${ }_{50}$ of A. hydrophila was $10^{5} \mathrm{cfu} / \mathrm{mL}$, which resulted in $50 \%$ of fish mortality. Therefore, concentration of $A$. hydrophila for following experiment was $10^{5} \mathrm{cfu} / \mathrm{mL}$.

\section{Disease Resistance of Progeny}

Survival of catfish juveniles challenged for 12 days is presented in Figure 2. The mean survival of fish having the MHC II marker $(77.50 \pm 4.00 \%$ was higher $(P<0.05)$ than that of fish without the marker $(53.33$ $\pm 4.77 \%$. The data indicated that catfish with positive MHC-II markers had durability and immune response better than that of negative MHC-II markers. Low survival rate of the fish with negative MHC-II markers may associate with low production of anti- bodies, thus they are highly dependent on innate immunity (non-specific immune) against pathogen infection. MHC-II markers in catfish may stimulate immune system in particular for producing antibodies by B lymphocytes, thus increasing immune system in response to pathogen infection. Lymphocytes are the blood cells responsible for production of antibodies against infections, either bacterial or viral. This is confirmed by Azis (2016) that the survival rate of catfish carrying MHC-I markers was 2,21 times higher than the control (negative MHC I markers). Hayuningtyas et al. (2013) also found that immune response was typically associated with molecules of MHC class I and MHC class II.

\section{Clinical Symptoms}

Clinical symptoms of fish were observed during the 12 days of challenge test. On the $1^{\text {st }}$ day to $3^{\text {rd }}$ day, haemorrhage and lesions were found in fish body (Figure $3 a)$. On the $4^{\text {th }}$ day to $6^{\text {th }}$ day, the wound enlarged, and some dead fish were found (Figure $3 b$ ). These clinical symptoms were relatively similar to the fish carrying and not carrying MHC-II markers. On the $7^{\text {th }}$ day to $9^{\text {th }}$ day, the wounds in some fish were reduced, and then wound closure was observed on the $10^{\text {th }}$ day (Figure 3c). Fish after infected bacteria A. hydrophila showed clinical symptoms, which was present around the injection site, and found in all fish after 24 hour of infection. The symptoms were indicated by presence of bruise around injection area on the fin, loss of appetite, abnormal swimming (weak and vertical), loss of barbels, peeling skin, presence of ulcers, and haemorrhage. Infection of A. hydrophila caused clinical symptoms in few hours after infec-

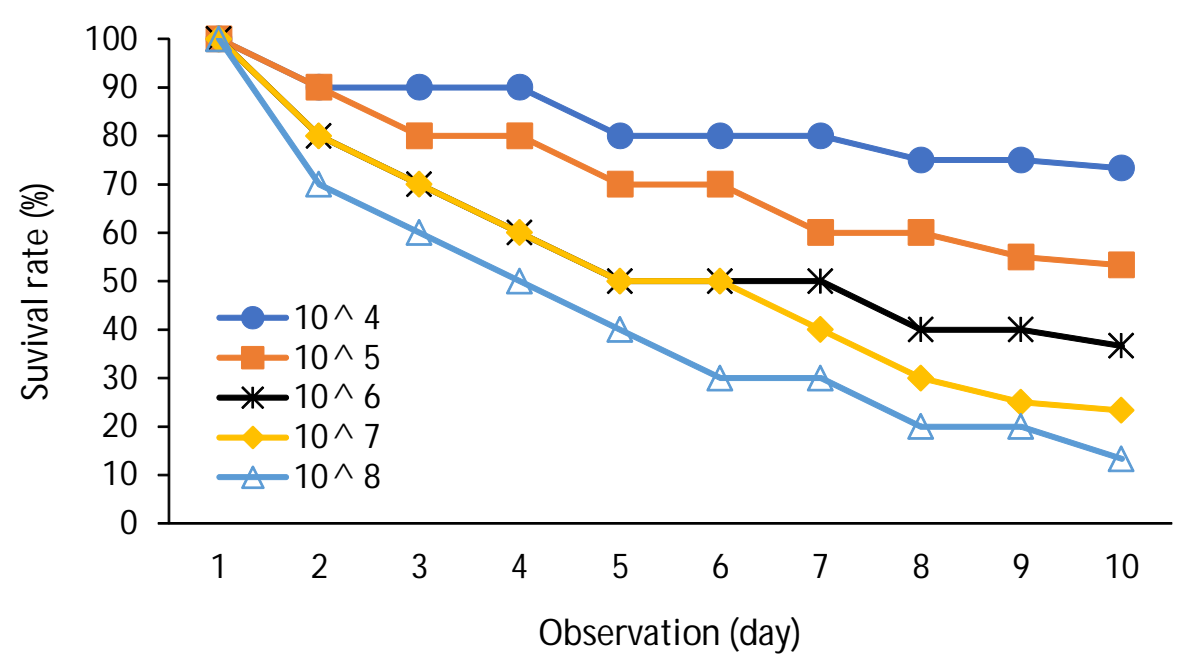

Figure 1. Survival rate (\%) of experimental fish infected by various doses of Aeromonas hydrophila for determination of $L_{50}$. 


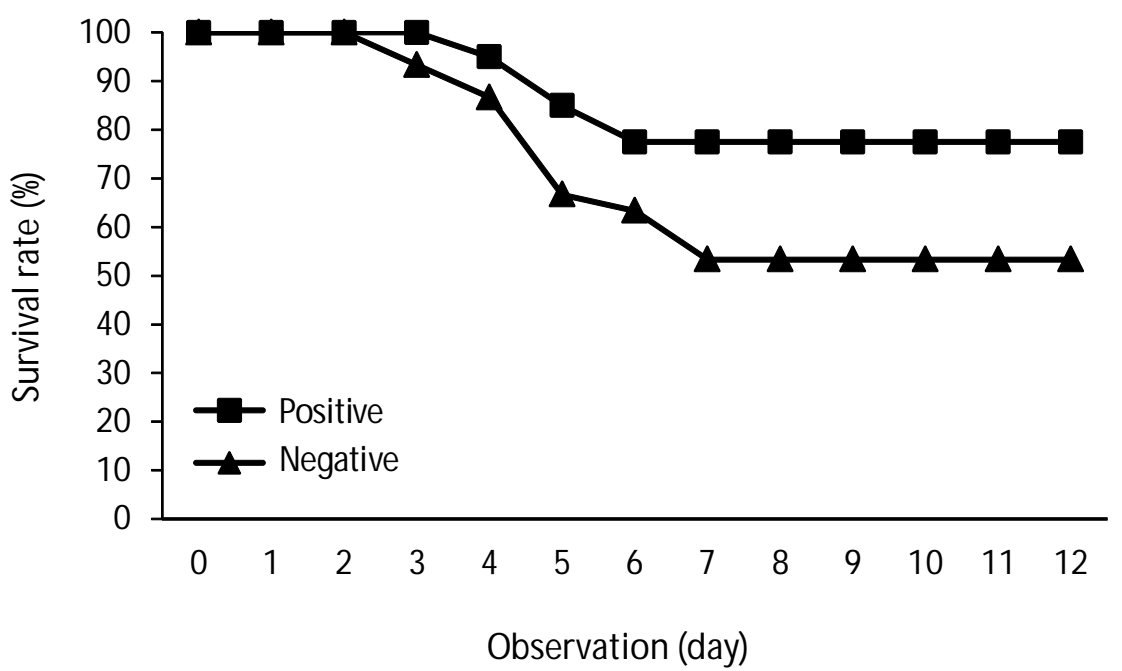

Figure 2. Survival rate of fish seed from broodstock carrying (positive) and not carrying MHC II markers (negative) after injection of A. hydrophilafor 12 days.

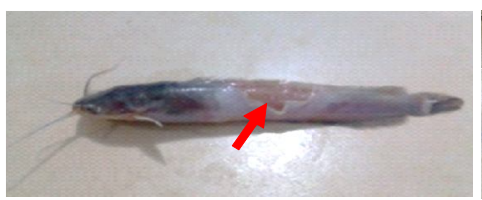

(a)

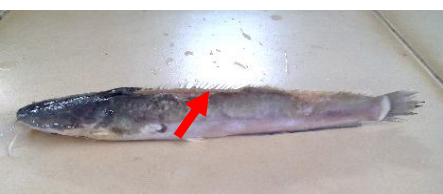

(b)

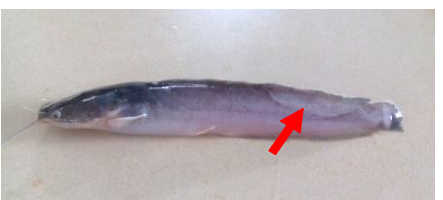

(c)

Figure 3. Fish condition after injection of Aeromonas hydrophila on (a) $3^{\text {rd }}$ day, (b) $6^{\text {th }}$ day, (c) $9^{\text {th }}$ day.

tion, led to mortality after seven hour of infection, and resulted in higher mortality of fish after 12-24 hour of infection (Wulandari et al., 2014).

\section{Fish Blood Profiles Post-Challenged with A. hydrophila}

Blood of catfish after challenge test of A. hydrophila was presented in Table 1. Total erythrocytes (TE), total leukocyte (TL), phagocytic activity (PA), and hematocrit $(\mathrm{Ht})$ of experimental fish increased on the $3^{\text {rd }}$ day to $6^{\text {th }}$ day, and decreased on the $9^{\text {th }}$ day to $12^{\text {th }}$ day for some parameters, indicating stabilization of live fish. However, we could observe that fish carrying MHC-II markers have better profile than those not carrying MHC-II markers.

Blood profile has been widely used as indicator of the health status of some fish species (Santos et al., 2012; Sayed \& Moneeb, 2015). Blood profile is also useful to be direct indicators since it provides information related to tolerance to a stressor or fish disease agents such as viruses and bacteria (Daneshvar et al., 2012). Blood profile was observed before and after injection to understand fish immune response. We found that all blood profiles showed similar pattern, indicating that immune response of fish with positive MHC-II markers was better than those with negative M HC-II markers. Total erythrocyte after challenge test for all treatments was decreased until the $6^{\text {th }}$ day, compared with prior to challenge test. Increased total erythrocyte was observed in the $9^{\text {th }}$ day to $12^{\text {th }}$ day, which was linked with clinical symptoms after challenge test. Bailone et al. (2010) reported that the decrease in erythrocytes and hemoglobin levels could be caused by infection of bacterial agents.

In the other hand, total leukocyte increased in all treatments after challenge test, which demonstrated fish defense against bacterial infection by $A$. hydrophila. Total leukocytes increased significantly until the $6^{\text {th }}$ day. The condition was in line with the clinical symptoms demonstrated by the appearance of ulcers and haemorrhage. On the $9^{\text {th }}$ day and $12^{\text {th }}$ day, total leukocyte showed no remarkable change due to wound closure. The increase in leukocyte cells was a fish response against infectious diseases 
Table 1. Total erythrocytes (TE), total leukocyte (TL), phagocytic activity (PA), and hematocrit (Ht) of Clarias sp. infected by Aeromonas hydrophila

\begin{tabular}{|c|c|c|c|c|c|c|c|}
\hline \multirow{2}{*}{ Parameters } & \multirow{2}{*}{ Treatments } & \multicolumn{5}{|c|}{ Observation (day) } & \multirow{2}{*}{$\begin{array}{l}\text { Normal } \\
\text { values }\end{array}$} \\
\hline & & 0 & 3 & 6 & 9 & 12 & \\
\hline \multirow{2}{*}{$\begin{array}{c}\text { TE } \\
\left(\times 106 \text { cells } \mathrm{mm}^{3}{ }^{3}\right)\end{array}$} & $A$ & $1.81 \pm 0.14$ & $0.73 \pm 0.06$ & $0.98 \pm 0.09$ & $1.41 \pm 0.75$ & $1.77 \pm 0.28$ & \multirow{2}{*}{$1.05-3.00^{1)}$} \\
\hline & B & $1.75 \pm 0.12$ & $0.61 \pm 0.20$ & $0.73 \pm 0.03$ & $1.34 \pm 0.68$ & $1.60 \pm 0.10$ & \\
\hline \multirow{2}{*}{$\begin{array}{c}\mathrm{TL} \\
\left(\times 105 \text { cells } \mathrm{mm}^{3}{ }^{3}\right)\end{array}$} & A & $1.30 \pm 0.17$ & $1.88 \pm 0.40$ & $2.51 \pm 0.08$ & $2.40 \pm 0.51$ & $1.94 \pm 0.16$ & \multirow{2}{*}{$0.2-1.5^{2)}$} \\
\hline & B & $1.27 \pm 0.11$ & $1.89 \pm 0.69$ & $2.62 \pm 0.01$ & $2.19 \pm 0.47$ & $1.77 \pm 0.15$ & \\
\hline \multirow{2}{*}{ PA (\%) } & A & $29.50 \pm 3.11$ & $31.25 \pm 0.96$ & $35.75 \pm 5.19$ & $45.50 \pm 3.11$ & $40.53 \pm 2.65$ & \multirow{2}{*}{$33.7-42.3^{31}$} \\
\hline & B & $28.33 \pm 3.51$ & $29.00 \pm 1.00$ & $36.33 \pm 4.73$ & $41.00 \pm 5.29$ & $39.67 \pm 1.53$ & \\
\hline \multirow{2}{*}{ Ht (\%) } & $A$ & $31.39 \pm 2.98$ & $24.49 \pm 6.73$ & $27.82 \pm 7.54$ & $29.48 \pm 2.22$ & $32.58 \pm 4.78$ & \multirow{2}{*}{$30.845 .5^{4)}$} \\
\hline & B & $31.78 \pm 4.19$ & $22.94 \pm 6.30$ & $27.69 \pm 6.66$ & $28.84 \pm 3.84$ & $32.38 \pm 1.62$ & \\
\hline
\end{tabular}

Note:

A means fish carrying MHC-II markers, while B means fish not carrying MHC-II markers, infected by A. hydrophila. 1) Roberts \& Richard (1978), 2) Moyle \& Chech (1988), 3) Sukendar (2016), and 4) Angka et al. (1985)

(Kurniawan et al., 2014). Sukenda et al. (2016) reported that leukocyte cells function as phagocytes to prevent unwanted bacteria and spread of virulence factors in fish body.

Phagocytic activity demonstrates the ability of phagocytic cells to perform phagocytosis against foreign objects that enter the host body. Table 1 indicated that phagocytic cells in infected fish were more active to form defense response against $A$. hydrophila. High phagocytic activity in injured fish resulted from immune mechanisms of fish as a defensive response to bacterial attack through various activities. This is augmented by Lukistyowati \& Kurniasih (2011), that leukocytes have the ability to fagocyt bacteria to defend themselves against pathogen attack. Therefore, presence of leukocytes was proportionally correlated with phagocytic activity.

Hematocrit is the ratio between red blood cells and blood plasma, and it affects the regulation of red blood cells. Increase in erythrocytes is associated with increase in hematocrit. Hematocrit decreased from the $3^{\text {rd }}$ day, and tend to increase on the $6^{\text {th }}$ day to $12^{\text {th }}$ day. Fluctuation of hematocrit after injection of A. hydrophila was caused by a bacterial infection responsible for degdradation of red blood cells. Low levels of hematocrit in experimental fish was supposedly due to anemic. Alamanda et al. (2007) reported that low level of hematocrit was an indicator of anemia in fish. It may also induce stress condition and mortality for fish.

\section{Primer Design}

Primer 2B for MHC-II markers in catfish was designed by aligning the MHC-II alleles as two primer sets in Channel catfish (Ictalurus punctatus) with the catfish genome of $C$. gariepinus, and obtained a set of the most suitable primer; i.e. forward primer (5'ATGTCCAAGCTGCTGAAGATT-3') and reverse primer (5'-TGCCGTCTGACTTCTTCACC-3'). The sequences were alligned using Basic Local Alignment Search Tool (BLAST ${ }^{\circledR}$ ).

\section{Marker Inheritance}

Analysis of marker presence using PCR on catfish seed was presented in Figure 4. Fish carrying MHC-II markers have a specific DNA band at 426 bp. Overall, broodstock carrying MHC-II markers resulted in fish that carried markers in $80 \%$ of resistant fish $(T+)$, and $40 \%$ of dead fish $(M+)$, whereas all live fish (T-) and dead fish (M-) from non markers-carrying broodfish showed no DNA bands from PCR amplification. The absence of the DNA bands in negative controls (N) indicated that there was no contamination in the PCR amplification process. Subsequently, PCR using â-actin generated DNA bands for all samples of the same size (about $300 \mathrm{bp}$ ). This finding demonstrated that experimental fish that had no PCR products when using the primer MHC-II was not due to absence of DNA template, but absence of DNA target (MHC-II) on the fish.

PCR amplification indicated DNA bands of $426 \mathrm{bp}$, indicating that the experimental fish had $\mathrm{MHC}$ II genes related to MAS resistance. Aziz et al. (2015a) also reported that the catfish had MHCI genes which correlated with resistance against $A$. hydrophila, but the PCR products of MHC-I markers showed no a single DNA band, about $300 \mathrm{bp}, 500 \mathrm{bp}$, and 1,000 bp. This previous study was dissimilar to our study that found 


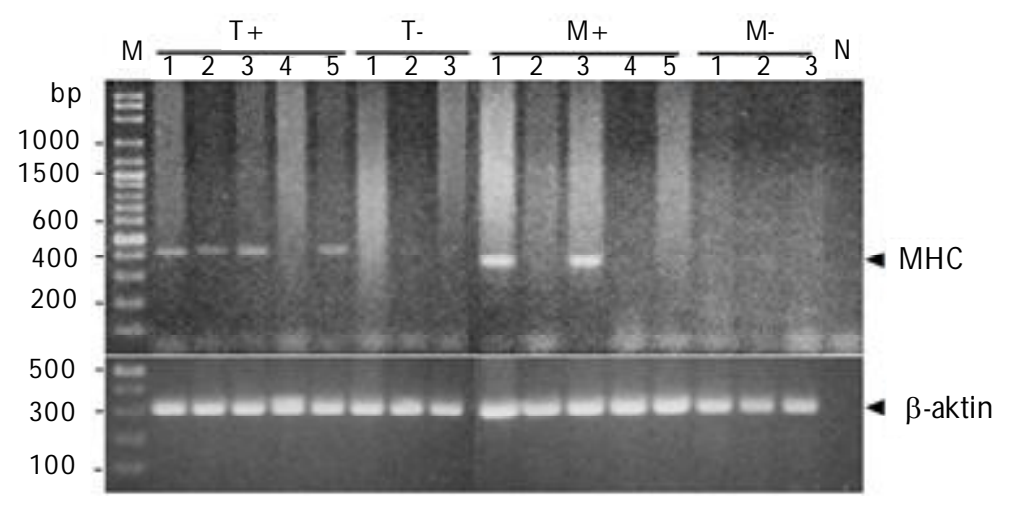

Figure 4. Result of PCR amplification in the detection of molecular markers with gene targets major histocompatibility complex (MHC-II) on the catfish (Clarias sp.). $\beta$-actin was used as DNA loading control. $M=$ markers of DNA fragment size (Vivantis); $T+(1-5)=$ resistant fish from broodstock carrying markers; $T$ (1$3)=$ resistant fish from broodstock not carrying markers; $M+(1-5)=$ dead fish from broodstock carrying markers; $M(1-3)=$ dead fish from broodstock not carrying markers; and $\mathrm{N}=$ the PCR products without DNA template.

a single DNA band, leading to easily observe inheritance of MHC-Il to the next generation. Pang et al. (2013) reported that MHC genes showed an important role in immune defense and disease control. High polymorphism is one of the most important characters of MHC genes, which provide the basis for screening disease resistant genes associated with molecular markers.

MHC-II genes were also revealed to be inherited to the next generation. The percentage of fish seed carrying MHC-II markers from broodstocks as MHCII carrier was $80 \%$ in resistant fish and $40 \%$ in dead fish, while broodstock with negative MHC-II markers showed consistent results, indicated by absence of DNA band $(0 \%$. These results indicate that MHC-II genes can be inherited in the first generation only from broodstock carrying M HC-II markers. Disappearance of MHC-II genes in the experimental fish with negative MHC-II markers was confirmed using â-actin primer for all samples. Amplification of â-actin in all samples yielded DNA band of approximately 300 bp, thus genomic DNA of all samples was in good condition, and disappearance of MHC-II gene was not due to the quality and inadequate amount of genomic DNA. Aziz et al. (2015b) also reported that the inheritance of MHC-I molecular markers was 83.4\%in F-1 fish carrying $\mathrm{MHC}-\mathrm{I}$ genes, and $25 \%$ in control fish carrying MHC-I genes.

Results of PCR amplification supported survival rate data, that survival rate of catfish carrying M HC-II markers was better and significantly different with catfish not carrying M HC-II markers $(P<0.05)$. In other words, M HC-II genes can serve as markers for Mutiara strain of catfish that is resistant to MAS disease. Previous study conducted by Aziz et al. (2015a) also concluded that the fragment of the MHC-I could be as molecular markers for catfish resistant to $A$. hydrophila infection. Further research was required to enrich data and information, and to confirm hereditary characteristics of selection based on MHC-II markers on catfish for several next generations.

\section{CONCLUSION}

MHC-II marker linked to MAS disease resistance in catfish was successfully obtained. Catfish carrying MHC-II marker possessed PCR product of $426 \mathrm{bp}$. MHC-II marker and durability of catfish against MAS disease were inherited to their progenies. Therefore, selection of catfish resistant to MAS disease could be carried out using MHC-II markers. Further research related to inheritance of MHC-II markers and durability of next generation catfish was needed.

\section{ACKNOWLEDGEMENT}

Thanks to all technicians of Clarias catfish at the Research Institute for Fish Breeding Sukamandi, Indonesian for their assistance in preparing the fish and materials during research.

\section{REFERENCES}

Alamanda, I.E., Handajani, N.S., \& Budiharjo, A. (2007). The use of hematology method and blood endoparasite observation for determining catfish (Clarias gariepinus) health in fishery Mangkubumen, 
Boyolali. Biodiversitas, 8, 34-38 (in Indonesian with English abstract).

Alimuddin, Octavera, A., Arifin, O.Z., \& Sumantadinata, K. (2008). Characterization of â-actin promoter of tilapia Oreochromis niloticus. Jurnal Akuakultur Indonesia, 7(2), 115-127 (in Indonesian with English abstract).

Alimuddin, Mubinun, Santika, A., Carman, O., Faizal, I., \& Sumantadinata, K. (2011). Identification of the Majalaya common carp strain resistance to KHV infection using Cyca-DAB1*05 allele as a marker. Indonesian Aquaculture Journal, 6(2), 157163.

Anderson, D.P. \& Siwicky, A.K. (1993). Basic haematology and serology for fish health program. Paper Presented in Second Symposium on disease in Asian Aquaculture Aquatic Animal Health and Environment Phucket Thailand, p. 25-29.

Angka, S.L., Wongkar, G.T., \& Karwani. (1985). Blood picture and bacteria isolated from ulcered and crooked-black Clarias batrachus. Symposium on Pract. Measure for Preventing and Controlling Fish Disease. BIOTROP, 17 pp.

Azis, Alimuddin, Sukenda, \& Junior, M.Z. (2015a). Identification of MHC-I marker candidate in catfish (Clarias sp.) resistant Aeromonas hydrophila infection. J. Ris. Akuakultur, 10(2), 261-269 (in Indonesian with English abstract).

Azis, Alimuddin, Sukenda, \& Junior, M.Z. (2015b). MHC-I molecular marker inheritance and first generation catfish Clarias sp. resistance against Aeromonas hydrophila infection. Pakistan Journal of Biotechnology, 12(2), 131-137.

Azis. (2016). The use of MHC I molecular marker in the selection of catfish (Clarias sp.) resistance to Aeromonas hydrophila infection. Dissertation. Institut Pertanian Bogor (in Indonesian).

Bailone, R.L., Martins, M.L., Mouriño, J.L.P., Vieira, F.N., Pedrotti, F.S., Nunes, G.C., \& Silva, B.C. (2010). Hematology and agglutination titer after polyvalent immunization and subsequent challenge with Aeromonas hydrophila in nile tilapia Oreochromis niloticus. Archivos de M edicina Veterinaria, 42, 221227.

Daneshvar, E., Ardestani, M.Y., Dorafshan, S., \& Martins, M.C. (2012). Hematological parameters of Iranian cichlid Iranocichla hormuzensis (Coad 1982), Perciformes in Mehran river. Anais da Academia Brasileira de Ciencias, 84(4), 943-949.

Hayuningtyas, E.P., Ariyanto, D., \& Syahputra, K. (2013). A correlation between growth character and presence of Major Histocompatibility Complex $(\mathrm{MHC})$ gene as disease resistance marker in common carp (Cyprinus carpio). J. Ris. Akuakultur, 8(3), 383-391 (in Indonesian with English abstract).

Kurniawan, A., Sarjito, \& Prayitno, S.B. (2014). Effect of Anredera cordifolia leaf extract on food toward hematology and survival rate of Clarias gariepinus infected by Aeromonas caviae. Journal of Aquaculture Management and Technology, 3, 76-85 (in Indonesian with English abstract).

Li, W., Sun, W.X., Hu, J.F., Hong, D.W., \& Chen, S.L. (2014). Molecular characterization, polymorphism and expression analysis of swamp eel MHC class Il b gene, after infection by Aeromonas hydrophila. Journal of Animal and Plant Sciences, 24(2), 481-491.

Lukistyowati, I. \& Kurniasih. (2011). The survival of Cyprinus carpio fed garlic extract Allium sativumi and infected Aeromonas hydrophila. Jurnal Perikanan dan Kelautan, 16(1), 144-160 (in Indonesian with English abstract).

Moulana, M., Evenhuis, J., Albertino, M., Godwin, U., Kountikov, E.I., Stuge, T.B., Wilson, M., Bengte' n, E., Miller, N.W., \& McConnell, T.J. (2008). Characterization of anti-channel catfish MHC class IIb monoclonal antibodies. Veterinary Immunology and Immunopathology, 126, 120-130.

Moyle, P.B. \& Cech Jr.J.J. (1988). Fishes an Introduction to Icthyology. USA: Prentice Hall Inc., 559 pp.

Nabib, R. \& Pasaribu, F.H. (1989). Pathology and fish disease. Departemen Pendidikan dan Kebudayaan. Direktorat Jendral Bioteknologi. Institut Pertanian Bogor. Bogor, $158 \mathrm{pp}$ (in Indonesian).

Pang, J.C., Gao, F.Y., Lu, M.X., Ye, X., Zhu, H.P., \& Ke, $X . L$. (2013). Major histocompatibility complex class IIA and IIB genes of nile tilapia Oreochromis niloticus: Genomic structure, molecular polymorphism and expression patterns. Fish and Shellfish Immunology, 34, 486-496.

Poonsawat, S., Areechon, N., Srisapoome, P., Maita, M., \& Endo, M. (2009). Polymorphism of MHC class I alpha cDNA and resistance against streptococcosis of six strains of Nile tilapia Oreochromis niloticus (Linnaeus). Kasetsart J. (Nat Sci), 43, 348357.

Rakus, K.f. (2008). Major Histocompatibility (MH) polymorphism of common carp. Link with disease resistance. Dissertation. Wageningen University.

Reed, L.J. \& Muench, H. (1938). A simple method of estimating fifty per cent endpoints. American Journal of Hygiene, 27, 493-497.

Roberts, R.J. \& Richards, R.H. (1978). The bacteriology of teleosts in fish pathology. London (GB): Bailliere Tindal Book Publ. 
Santos, A.A., Ranzani-Paiva, M.J.T., Veiga, M.L., Faustino, L., \& Egami, M.I. (2012). Hematological parameters and phagocytic activity in fat snook Centropomus parallelus bred in captivity. Fish and Shellfish Immunollogy, 33, 953-961.

Sayed, A.E.H. \& Moneeb, R.H. (2015). Hematological and biochemical characters of monosex tilapia Oreochromis niloticus (Linnaeus 1758) cultivated using methyltestosterone. Journal of Basic Applied Zoology, 72, 36-42.

Seifertová, M. \& Šimková, A. (2011). Structure, diversity and evolutionary patterns of expressed MHC class IIB genes in chub Squalius cephalus, a cyprinid fish species from Europe. Immunogen, 63, 167-181.

Sukenda, Rafsyanzani, M.M., Rahman, \& Hidayatullah, D. (2016). Performance of Bacillus sp. probiotic in catfish juvenile Clarias sp. infected by Aeromonas hydrophila. Jurnal Akuakultur Indonesia, 15(2), 162170 (in Indonesian with English abstract).

Sukendar, W. (2016). Immune response and growth performance of catfish in biofloc system with different carbon sources which infected by Aeromonas hydrophila. Thesis. Institut Pertanian Bogor (in Indonesian).

Taukhid, Purwaningsih, U., Sugiani, D., Sumiati, T., \& Lusiastuti, A.M. (2015). Efficacious of in-active bacterial vaccines: Aeromonas hydrophila-AHL09052 (Hydrovac) and Streptococcus agalactiae-N14G (Streptovac) for prevention of bacterial diseases on freshwater aquaculture. J. Ris. Akuakultur, 10(4), 541-551 (in Indonesian with English abstract).

Wahjuningrum, D., Solikhah, E.H., Budiardi, T., \& Setiawati, M. (2010). Infection control of Aeromonas hydrophila in catfish (Clarias sp.) using mixture of meniran Phyllanthus niruri and garlic Allium sativum in feed. Jurnal Akuakultur Indonesia, 9(2), 93-103 (in Indonesian with English abstract).

Wulandari, D.A., Prayitno, S.B., \& Sarjito. (2014). Pathogenicity of isolated K14 from catfish (Clarias gariepinus) from Demak. Journal of Aquaculture Management and Technology, 3(2), 143-149 (in Indonesian with English abstract). 